\title{
LIN28B, LIN28A, KISS1, and KISS1R in idiopathic central precocious puberty
}

\author{
Johanna Tommiska ${ }^{1,2^{*}}$, Kaspar Sørensen ${ }^{3}$, Lise Aksglaede ${ }^{3}$, Rosanna Koivu ${ }^{1,2}$, Lea Puhakka ${ }^{1,2}$, Anders Juul ${ }^{3}$ and \\ Taneli Raivio ${ }^{1,2}$
}

\begin{abstract}
Background: Pubertal timing is a strongly heritable trait, but no single puberty gene has been identified. Thus, the genetic background of idiopathic central precocious puberty (ICPP) is poorly understood. Overall, the genetic modulation of pubertal onset most likely arises from the additive effect of multiple genes, but also monogenic causes of ICPP probably exist, as cases of familial ICPP have been reported. Mutations in KISSI and KISSR, coding for kisspeptin and its receptor, involved in GnRH secretion and puberty onset, have been suggested causative for monogenic ICPP. Variation in LIN28B was associated with timing of puberty in genome-wide association (GWA) studies. LIN28B is a human ortholog of the gene that controls, through microRNAs, developmental timing in C. elegans. In addition, Lin28a transgenic mice manifest the puberty phenotypes identified in the human GWAS. Thus, both LIN28B and LIN28A may have a role in pubertal development and are good candidate genes for monogenic ICPP.
\end{abstract}

Methods: Thirty girls with ICPP were included in the study. ICPP was defined by pubertal onset before 8 yrs of age, and a pubertal LH response to GnRH testing. The coding regions of LIN28B, LIN28A, KISS1, and KISS1R were sequenced. The missense change in LIN28B was also screened in 132 control subjects.

Results: No rare variants were detected in KISS1 or KISSIR in the 30 subjects with ICPP. In LIN28B, one missense change, His199Arg, was found in one subject with ICPP. However, this variant was also detected in one of the 132 controls. No variation in LIN28A was found.

Conclusions: We did not find any evidence that mutations in LIN28B or LIN28A would underlie ICPP. In addition, we confirmed that mutations in KISSI and KISSIR are not a common cause for ICPP.

Keywords: LIN28B, LIN28A, KISS1, KISS1R, idiopathic central precocious puberty, timing of puberty

\section{Background}

During the last decades, a decline in age at pubertal onset in girls has been reported worldwide [1,2], paralleled by an increase in the incidence of idiopathic central precocious puberty (ICPP) [3]. However, the etiology underlying the precocious reactivation of the hypothalamic-pituitary-gonadal (HPG) axis in girls with ICPP is still largely unresolved. As compared with normal-timed pubertal controls, girls with ICPP have increased adiposity and decreased insulin sensitivity at diagnosis, suggesting a causal link between these metabolic factors and HPG axis programming [4]. However,

\footnotetext{
* Correspondence: johanna.tommiska@helsinki.fi

${ }^{1}$ Institute of Biomedicine/Physiology, University of Helsinki, Helsinki, Finland Full list of author information is available at the end of the article
}

these metabolic factors may only elicit an early HPG activation in the presence of a susceptible genetic background. Overall, the genetic modulation of pubertal onset most likely arises from the additive effect of multiple genes [5], but also monogenic causes of ICPP probably exist, as cases of familial ICPP have been reported (reviewed in [5]). For example, a $27.5 \%$ prevalence of familial ICPP has been reported in one study; the suggested mode of inheritance was autosomal dominant with incomplete sex-dependent penetrance [6].

Only few genes have been investigated in mutation screening studies in ICPP. Inactivating mutations in the KISS1R (GPR54) gene cause autosomal recessive normosmic idiopathic hypogonadotropic hypogonadism (nIHH) [7]. KISS1R codes for a G protein-coupled

\section{() Biomed Central}


receptor which with its ligand, kisspeptin, forms an excitatory neuroregulator system for $\mathrm{GnRH}$ secretion. Interestingly, an autosomal dominant activating KISS1R mutation has been described in a girl with ICPP [8], and very recently, also mutations in KISS1, coding for kisspeptin, were suggested to underlie ICPP [9]. Thus, inactivating or activating mutations in the same key genes governing the HPG axis function may have respective effects on the phenotype. The role for KISS1R and KISS1 in ICPP has also been suggested in association analyses $[10,11]$. However, so far none of these results has been verified or replicated in other study populations. Especially, the frequencies of KISS1R and KISS1 mutations in other series of ICPP patients have not been reported.

Variation in or near the LIN28B gene has been found associated with age at menarche in four independent genome-wide association (GWA) studies [12-15], and, in one of them, the allele associated with earlier age at menarche was also associated with other markers of pubertal timing (earlier breast development; earlier voice breaking and more advanced pubic hair development; faster tempo of height growth and shorter adult height) [13]. We subsequently investigated whether mutations in the coding region of $L I N 28 B$ could account for delayed puberty in a large, well-phenotyped cohort of subjects with constitutional delay of growth and puberty (CDGP), but no mutations were found [16]. LIN28B is a human ortholog of the gene that regulates processing of microRNAs (miRNAs) which control the timing of major developmental events in C. elegans: gain-of-function and loss-of-function mutations result in retarded or precocious development, respectively [17]. In addition, Lin28a (functionally redundant homolog of Lin28b) transgenic mice manifest the puberty phenotypes identified in the human GWA studies [18]. Thus, both LIN28B and LIN28A may have a role in pubertal development and are good candidate genes for monogenic ICPP.

Here, we investigated mutations in LIN28B, LIN28A, KISS1, and KISS1R in 30 girls with ICPP.

\section{Methods}

\section{Subjects}

Thirty girls with ICPP were recruited from our outpatient clinic at the Department of Growth and Reproduction, Copenhagen University Hospital, Denmark. Details of this study have previously been published [4]. All patients presented with breast budding as first sign of puberty, and all were pre-menarcheal at diagnosis. The girls were diagnosed with ICCP if the following criteria were met: age at onset of breast development $<8$ yrs, peak-LH level > $5 \mathrm{IU} / \mathrm{l}$ in response to rapid-acting GnRHa (0.1 mg of Relefact ${ }^{\circledR}$ LH-RH), and a non- pathological brain MRI. In addition, bone age and sex steroid hormones were evaluated. The mean age at onset of puberty was 7.5 yrs (6.5-7.9) with a mean bone age advancement of 1.4 yrs $(-0.1-2.8)$. One hundred thirty-two healthy controls were recruited from The COPENHAGEN Puberty Study. This study has previously been described in details [1,19]. In brief, healthy girls and boys were recruited from primary schools in the Copenhagen area from May 2006 to January 2008. In total, 995 healthy Caucasian girls participated. Of these, the present sample represents all prepubertal girls aged 8.1-9.9 yrs with available DNA. Pubertal development (breast stage B1-B5 and pubic hair stage PH1PH5) was described according to Tanner's criteria supplemented with breast palpation to better discern true glandular breast tissue from adipose tissue.

\section{Mutation analysis}

Genomic DNA from peripheral blood leukocytes of the subjects was extracted. The coding exons and the exonintron boundaries of LIN28B, LIN28A, KISS1, and KISS1R were PCR amplified from all subjects with ICPP. In addition, exon 4 of $L I N 28 B$ was screened in DNA samples from 132 healthy control subjects. PCR products were purified with ExoSAP-IT treatment (Amersham Biosciences, Piscataway, NJ, USA), and sequenced using the ABI BigDyeTerminator Cycle Sequencing Kit (v3.0) and ABI 3730xl 96-capillary DNA Analyzer automated sequencer (Applied Biosystems, Foster City, CA, USA). Sequences were aligned and read with Sequencher ${ }^{\circledR} 4.9$ software (Gene Codes Corporation, Ann Arbor, MI, USA). All primer sequences and PCR conditions are available upon request.

\section{Ethics}

The study was approved by the local ethical committee (\# KF 01282214 and KF 11 2006-2033), and the Danish Data Protection Agency. All participants and their parents gave informed consents.

\section{Results and Discussion}

Only one sequence variant was found in the coding region of $L I N 28 B$; a missense change c.596A > G (p. His199Arg) (rs118000887) was detected in a girl with ICPP: her age at pubertal onset was 7.8 yrs, she was in Tanner stage B3 and PH2 at diagnosis (8.9 yrs), had bone age advancement of $2.1 \mathrm{yrs}$, and gonadotropin and estradiol levels consistent with an early activation of the HPG axis (plasma estradiol $131 \mathrm{pmol} / \mathrm{L}$; FSH 5.11 IU/L; LH 2.04 IU/L). This His199Arg change was predicted to be possibly damaging by PolyPhen http://genetics.bwh. harvard.edu/pph/[20,21], but it was also present in 1 of the 132 controls: this girl had Tanner stage B1 and PH1 at the age of $8.9 \mathrm{yrs}$, and she did not deviate from the 
other controls with respect to height, weight and BMI, as well as gonadotropins, sex steroids, SHBG, or IGF-1 levels (all her values were within the mean \pm 2 SDs of the controls). Thus, this missense change is not likely to be causative for ICPP, and it is not of clinical value in the early detection of girls at risk of ICPP. No sequence variation was detected in the coding region of LIN28A, a finding in accordance with the rarity of reported polymorphisms in this area http://www.ensembl.org/index. html[22]. We do realize that our sample size is small. However, if mutations in the coding region of LIN28B or LIN28A did cause $15 \%$ of ICPP, we would have with $99 \%$ probability found at least one mutation in 30 subjects. We can thus conclude that mutations in LIN28B and LIN28A are not at least a common cause for ICPP. Of course, as only coding regions of these genes were sequenced, there may be mutations outside these regions, not detected in our study. Especially, there are miRNA regulatory elements in the 3'UTR of LIN28B, mutations in which could affect the function of the gene and have an impact on the timing of puberty; in CDGP, however, this was not the case [16]. Involvement of LIN28B and LIN28A in the regulation of pubertal timing in humans still warrants further studies in different patient groups and populations.

In KISS1 and KISS1R, our cases carried only common previously known single nucleotide polymorphisms (SNPs) http://www.ensembl.org/index.html[22]. Given the central role of the kisspeptin-KISS1R signaling complex in the pubertal activation of GnRH neurons and the reproductive axis [7], a defective kisspeptin system appears to be an obvious candidate in the pathogenesis of sexual precocity. An autosomal dominant missense mutation, Arg386Pro, in KISS1R (GPR54), leading to prolonged activation of intracellular pathways in response to kisspeptin, has been suggested to cause central precocious puberty in an adopted girl whose biologic family was not available for genetic studies [8]. To the best of our knowledge, no other ICPP cases with activating KISS1R mutations have been reported. Recently, Silveira et al. [9] studied 83 children (77 girls) with ICPP for mutations in KISS1, and reported two missense variants, c.369C > T (p.Pro74Ser) and c.417C > G (p.His90Asp), in three unrelated children: two unrelated girls with sporadic ICPP were homozygous carriers of the variant His90Asp, and one boy with sporadic ICPP had a heterozygous Pro74Ser. These variants were not detected in 200 controls, but only Pro74Ser differed from the wild type in the in vitro studies: the variant appeared to result in higher kisspeptin resistance to degradation. However, the proband's mother and maternal grandmother were also carriers of the variant, but had menarche at appropriate ages. No mutations in KISS1 were found in 101 Korean girls with ICPP [23]; only known polymorphisms or synonymous changes were detected. In accordance, no mutations were found in either KISS1R or KISS1 in our 30 girls with ICPP, suggesting that defects in the kisspeptin system are a rare cause for ICPP. We cannot, however, rule out the possibility that mutations outside the coding regions, for example in the regulatory regions of these genes, could be found in these patients.

\section{Conclusions}

Our results suggest that mutations in the coding region of LIN28B or LIN28A do not play a major role, if any, in the genetic etiology of ICPP. In addition, we confirmed that mutations in KISS1 and KISS1R are not common causes of ICPP in girls.

\section{Funding}

This work was supported by the Kirsten and Freddy Johansen Foundation, the Danish Medical Research Council, the European Union (DEER, grant 212844), the Academy of Finland, the Foundation for Paediatric Research, the Helsinki University Central Hospital Research Funds, the Sigrid Juselius Foundation, Emil Aaltonen Foundation, Novo Nordisk Foundation, Jalmari and Rauha Ahokas Foundation, Finnish Cultural Foundation, and Helsinki University Research Funds.

\section{List of abbreviations}

ICPP: idiopathic central precocious puberty; GWA study: genome-wide association study; HPG axis: hypothalamic-pituitary-gonadal axis; $\mathrm{nlHH}$ : normosmic idiopathic hypogonadotropic hypogonadismi; CDGP: constitutional delay of growth and puberty; miRNA: microRNA; SNP: single nucleotide polymorphism

\section{Author details}

'Institute of Biomedicine/Physiology, University of Helsinki, Helsinki, Finland. ${ }^{2}$ Children's Hospital, Helsinki University Central Hospital (HUCH), Helsinki, Finland. ${ }^{3}$ Department of Growth and Reproduction, Copenhagen University Hospital, DK-2100 Copenhagen, Denmark.

\section{Authors' contributions}

JT participated in the study design, planned the molecular genetic studies, and drafted the manuscript. KS and LA collected the patient samples and clinical data in the study, and helped to draft the manuscript. RK and LP carried out most of the molecular genetic studies. AJ and TR participated in the study design and helped to draft the manuscript. All authors read and approved the final manuscript.

\section{Competing interests}

The authors declare that they have no competing interests.

Received: 1 July 2011 Accepted: 22 September 2011

Published: 22 September 2011

\section{References}

1. Aksglaede L, Sørensen K, Petersen JH, Skakkebaek NE, Juul A: Recent decline in age at breast development: the Copenhagen Puberty Study. Pediatrics 2009, 123:e932-939.

2. Herman-Giddens ME, Slora EJ, Wasserman RC, Bourdony CJ, Bhapkar MV, Koch GG, Hasemeier CM: Secondary sexual characteristics and menses in 
young girls seen in office practice: a study from the Pediatric Research in Office Settings network. Pediatrics 1997, 99:505-512.

3. Teilmann G, Pedersen CB, Jensen TK, Skakkebaek NE, Juul A: Prevalence and incidence of precocious pubertal development in Denmark: an epidemiologic study based on national registries. Pediatrics 2005, 116:1323-1328.

4. Sørensen K, Mouritsen A, Mogensen SS, Aksglaede L, Juul A: Insulin sensitivity and lipid profiles in girls with central precocious puberty before and during gonadal suppression. Journal of Clinical Endocrinology \& Metabolism 2010, 95:3736-3744.

5. Phillip M, Lazar L: Precocious puberty: growth and genetics. Hormone Research 2005, 64(Suppl 2):56-61.

6. de Vries L, Kauschansky A, Shohat M, Phillip M: Familial central precocious puberty suggests autosomal dominant inheritance. Journal of Clinical Endocrinology \& Metabolism 2004, 89:1794-1800.

7. Seminara SB, Messager S, Chatzidaki EE, Thresher RR, Acierno JS Jr, Shagoury JK, Bo-Abbas Y, Kuohung W, Schwinof KM, Hendrick AG, Zahn D, Dixon J, Kaiser UB, Slaugenhaupt SA, Gusella JF, O'Rahilly S, Carlton MB, Crowley WF Jr, Aparicio SA, Colledge WH: The GPR54 gene as a regulator of puberty. New England Journal of Medicine 2003, 349:1614-1627.

8. Teles MG, Bianco SD, Brito VN, Trarbach EB, Kuohung W, Xu S, Seminara SB, Mendonca BB, Kaiser UB, Latronico AC: A GPR54-activating mutation in a patient with central precocious puberty. New England Journal of Medicine 2008, 358:709-715.

9. Silveira LG, Noel SD, Silveira-Neto AP, Abreu AP, Brito VN, Santos MG, Bianco SD, Kuohung W, Xu S, Gryngarten M, Escobar ME, Arnhold IJ, Mendonca BB, Kaiser UB, Latronico AC: Mutations of the KISS1 Gene in Disorders of Puberty. Journal of Clinical Endocrinology \& Metabolism 2010, 95:2276-2280.

10. Luan X, Yu H, Wei X, Zhou Y, Wang W, Li P, Gan X, Wei D, Xiao J: GPR54 polymorphisms in Chinese girls with central precocious puberty. Neuroendocrinology 2007, 86:77-83.

11. Luan X, Zhou Y, Wang W, Yu H, Li P, Gan X, Wei D, Xiao J: Association study of the polymorphisms in the KISS1 gene with central precocious puberty in Chinese girls. European Journal of Endocrinology 2007 157:113-118.

12. Perry JR, Stolk L, Franceschini N, Lunetta KL, Zhai G, McArdle PF, Smith AV Aspelund T, Bandinelli S, Boerwinkle E, Cherkas L, Eiriksdottir G, Estrada K, Ferrucci L, Folsom AR, Garcia M, Gudnason V, Hofman A, Karasik D, Kiel DP, Launer $L$, van Meurs J, Nalls MA, Rivadeneira F, Shuldiner AR, Singleton A, Soranzo N, Tanaka T, Visser JA, Weedon MN, Wilson SG, Zhuang V, Streeten EA, Harris TB, Murray A, Spector TD, Demerath EW, Uitterlinden AG, Murabito JM: Meta-analysis of genome-wide association data identifies two loci influencing age at menarche. Nature Genetics 2009, 41:648-650.

13. Ong KK, Elks CE, Li S, Zhao JH, Luan J, Andersen LB, Bingham SA, Brage $S$, Smith GD, Ekelund U, Gillson CJ, Glaser B, Golding J, Hardy R, Khaw KT, Kuh D, Luben R, Marcus M, McGeehin MA, Ness AR, Northstone K, Ring SM, Rubin C, Sims MA, Song K, Strachan DP, Vollenweider P, Waeber G, Waterworth DM, Wong A, Deloukas P, Barroso I, Mooser V, Loos RJ, Wareham NJ: Genetic variation in LIN28B is associated with the timing of puberty. Nature Genetics 2009, 41:729-733.

14. He C, Kraft P, Chen C, Buring JE, Paré G, Hankinson SE, Chanock SJ, Ridker PM, Hunter DJ, Chasman DI: Genome-wide association studies identify loci associated with age at menarche and age at natural menopause. Nature Genetics 2009, 41:724-728.

15. Sulem P, Gudbjartsson DF, Rafnar T, Holm H, Olafsdottir EJ, Olafsdottir GH, Jonsson T, Alexandersen P, Feenstra B, Boyd HA, Aben KK, Verbeek AL, Roeleveld N, Jonasdottir A, Styrkarsdottir U, Steinthorsdottir V, Karason A, Stacey SN, Gudmundsson J, Jakobsdottir M, Thorleifsson G, Hardarson G, Gulcher J, Kong A, Kiemeney LA, Melbye M, Christiansen C, Tryggvadottir L, Thorsteinsdottir U, Stefansson K: Genome-wide association study identifies sequence variants on $6 \mathrm{q} 21$ associated with age at menarche. Nature Genetics 2009, 41:734-738.

16. Tommiska J, Wehkalampi K, Vaaralahti K, Laitinen EM, Raivio T, Dunkel L: LIN28B in constitutional delay of growth and puberty. Journal of Clinical Endocrinology \& Metabolism 2010, 95:3063-3066.

17. Moss EG, Lee RC, Ambros V: The cold shock domain protein LIN-28 controls developmental timing in C. elegans and is regulated by the lin4 RNA. Cell 1997, 88:637-646.

18. Zhu H, Shah S, Shyh-Chang N, Shinoda G, Einhorn WS, Viswanathan SR, Takeuchi A, Grasemann C, Rinn JL, Lopez MF, Hirschhorn JN, Palmert MR,
Daley GQ: Lin28a transgenic mice manifest size and puberty phenotypes identified in human genetic association studies. Nature Genetics 2010, 42:626-630.

19. Sørensen K, Aksglaede L, Petersen JH, Juul A: Recent changes in pubertal timing in healthy Danish boys: associations with body mass index. Journal of Clinical Endocrinology \& Metabolism 2010, 95:263-270.

20. Ramensky V, Bork P, Sunyaev S: Human non-synonymous SNPs: Server and survey. Nucleic Acids Research 2002, 30:3894-3900.

21. PolyPhen: prediction of functional effect of human nsSNPs. [http:// genetics.bwh.harvard.edu/pph/].

22. Ensembl Genome Browser. [http://www.ensembl.org/index.html].

23. Ko JM, Lee HS, Hwang JS: KISS1 gene analysis in Korean girls with central precocious puberty: a polymorphism, p.P110T, suggested to exert a protective effect. Endocrine Journal 2010, 57:701-709.

doi:10.1186/1756-0500-4-363

Cite this article as: Tommiska et al.: LIN28B, LIN28A, KISS1, and KISS1R in idiopathic central precocious puberty. BMC Research Notes 2011 4:363.

\section{Submit your next manuscript to BioMed Central and take full advantage of:}

- Convenient online submission

- Thorough peer review

- No space constraints or color figure charges

- Immediate publication on acceptance

- Inclusion in PubMed, CAS, Scopus and Google Scholar

- Research which is freely available for redistribution

Submit your manuscript at www.biomedcentral.com/submit
Ciomed Central 